\title{
COMMENT ON MCNOLLGAST "LEGISLATIVE INTENT"
}

\author{
ROBERT H. BATES*
}

\section{INTRODUCTION}

McNollgast's article on legislative intent can be viewed as an exercise in textual interpretation. ${ }^{1}$ As such, it represents an alternative to the currently fashionable interpretive school of legal studies. Rather than play positive political theory off against its contemporary rival, however, this comment will instead play it off against an earlier research tradition: the studies of persuasive communications undertaken by sociologists, social psychologists, and political scientists of the behavioral tradition. Doing so helps to highlight the significance of McNollgast's basic strategy as well as possible weaknesses in its application.

I refer back to this earlier tradition because its goal is similar to that of McNollgast. While the former studied mass media messages and the latter study statutes, the basic problem they both address is the attempt to understand the content and impact of persuasive messages. The lessons learned from experience with the one can therefore be applied to the other.

II

\section{MEDIA STUdiEs}

I did my graduate work in political science at the Massachusetts Institute of Technology, and, as did most others who passed through the department at that time, I studied the field of "communications." The field formed the core of M.I.T.'s political science curriculum, reflecting the centrality of Ithiel de Sola Pool, Daniel Lerner, and Lucian Pye, and concentrated on the study of persuasive communications. Developed to analyze the mass media, the field received its primary impetus from the desire of social scientists and policymakers to understand the rise of totalitarianism and, in particular, the political potency of Nazi propaganda. Students of mass communications attempted to account for the content of persuasive political messages and their impact upon public opinion.

Communications research was empirically, rather than theoretically, driven. In its North American guise, it began with a "busted" research project-the

Copyright $\odot 1994$ by Law and Contemporary Problems

* Professor of Political Science, Harvard University.

1. McNollgast, The Use of Positive Political Theory in Statutory Interpretation, 57 LAw \& CONTEMP. PROBS. 3 (Winter 1994). 
famed Erie County study of the Roosevelt-Wilkie election of $1940 .^{2}$ In an attempt to improve their research, scholars struggled to perfect their research designs, heightening their capacity to control and measure key variables. The result was a series of increasingly sophisticated studies over a period of nearly three decades, giving rise to one of the few genuinely cumulative research traditions in the social sciences. ${ }^{3}$ The magnitude and quality of this research effort is suggested by the methodological innovations that it introduced, including survey research, panel studies, experimental methods, ${ }^{4}$ laboratory research, ${ }^{5}$ field experiments, ${ }^{6}$ and content analysis. ${ }^{7}$

Communications research focused on a subject of compelling significance, and its practitioners were true scientists who perfected methods of observation, inference, and measurement. And, yet, few of us who attended M.I.T. chose to remain in the field. There were various reasons, but for purposes of this discussion only one is central, for it bears upon McNollgast's project.

The difficulty faced by students of the mass media was perhaps best signaled by the agenda offered for the field by Harold Lasswell, one of its founders. Lasswell defined the study of communications as the study of who says what to whom and with what effect. ${ }^{8}$ As suggested by the increasingly convoluted experimental variations undertaken by Hovland and his colleagues, ${ }^{9}$ this formulation underscored the complex series of causal factors affecting the content of any communicative act. Factors shaping the content of the communication would include the following:

1. The communicator herself: her preferences, her intentions, her stature and credibility, her perception of the audience.

2. The audience: including its interest in the subject, its preferences, its perceptions of the communicator and the message and its exposure to other communicative acts.

3. The communicative situation: including whether the audience is pre-selected or not, or captive or not.

The problem is clear: there is often but one piece of data, the text, but there are a multitude of complexly interrelated variables that determine the content of the

2. The report on this project is contained in Paul Lazarsfeld et AL., The PeOPLE'S ChOice (1944). See especially the prefaces contained in the 1968 edition.

3. The apex of this research was perhaps achieved in Coleman, Katz, and Menzel's study of the impact of advertising on the medical choices of doctors. JAMES S. COLEMAN ET AL., MEDICAL INNOVATION (1966). The best overview of this research tradition is Elihu Katz, The Two-Step Flow of Communication, PUB. OPINION Q. 21, 61-78 (1957).

4. See, e.g., Carl I. Hovland et al., Communication and Persuasion (1953).

5. See Alex Bavelas, Communications Patterns in Task Oriented Groups, in THE POLICY SCIENCES (Daniel Lerner \& Harold D. Lasswell eds., 1951).

6. LeON Festinger et AL., SOCIAL PRESSURES in INFORMAL GroupS (1950).

7. Ithiel de Sola PoOl et al., The Prestige Papers (1952).

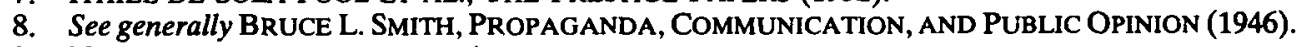

9. HoVlaND ET AL., supra note 4. 
text. Put crudely, the number of variables vastly exceeds the number of observations. Phrased more elegantly (at least for a social science audience), there is a problem of identification. Regardless of the way it is stated, there is a massive problem of inference. Despite the brilliance of the investigators, then, it seemed to many that the field was reaching a dead end, and many of us got out of it.

The McNollgast article suggests that it may be time to get back in. One way of resolving an identification problem is to introduce constraints on the values or relationships between variables, either by drawing on "external" information-such as prior experience-or on theory. Heavily empirical in its orientation, the field of communications research lacked a strong corpus of theory that would enable it to restrict the value of or relations among the variables possibly affecting the content of communications. Viewed in this light, the basic contribution of McNollgast is to propose and use such a theorypositive political theory ("PPT")-and thereby to attempt to overcome the problems of inference encountered by their predecessors.

\section{III}

\section{SOME CRITICISMS}

In the oral delivery of their article, the authors stressed the power of PPT as a tool for creating inferences concerning the content of texts-in this case, legislative acts. Should PPT be able to play this role, this would, indeed, represent a major contribution. But in light of the comments made above, one is also entitled to ask whether it is PPT or prior experience that the authors most fruitfully bring to bear.

Upon reading their article, I am inclined to think that past experience, rather than theory, plays the greater role. The existence of multiple decision points, the broad distribution of veto power, the general composition of the enabling coalition-all these stylized facts of legislative politics were well established before they were incorporated into PPTs of the U. S. Congress. They were established not by theorists but by political scientists "soaking and poking" in the everyday life of the Congress. The most important contribution of their theory, then, lies rather in the assumption of rationality and in the consequent appreciation of the significance of backward induction. These elements of PPT lead to inferences that might otherwise be missed; to offer one example, the preferences and intentions of the president are incorporated into statutes that are signed into law, even though the president is not a member of the legislature.

I am less sanguine about other results "derived" from theory in the McNollgast article. In particular, McNollgast "derive" that spokespersons for the legislation-those acting on behalf of the enabling coalition-are constrained from strategic behavior; they are constrained truthfully to reveal their preferences. But PPT suggests that given the rules for the enactment of legislation and the fact of judicial review, those moving earlier in the game tree-that is, the enabling coalition-would anticipate the preferences of the court itself. The 
legislating coalition might therefore itself behave strategically. The leaders of the coalition, while faithfully reflecting its members' preferences, might be articulating points of view that themselves are strategically contrived. The result, then, is a contradiction in reasoning.

The major point I wish to make is that without incorporation of the anticipated reaction of the judicial system, the theoretical program propounded by McNollgast is not fully realized. This point notwithstanding, the spirit of these comments is positive and constructive. I make them in an effort to highlight and accentuate the contributions that McNollgast and PPT can make in this effort to interpret the meaning of texts or, in this instance, the intention of statutes. 